\title{
Interaction of B-rich supercritical magmatic fluids with granite: first report of dumortierite in Larderello, Italy
}

\author{
Mariano Puxeddu, ${ }^{1, *}$ \\ ${ }^{1}$ Istituto di Geoscienze e Georisorse, CNR, via Moruzzi 1, 56124 Pisa, Italy
}

\begin{abstract}
In a peraluminous two-mica monzogranite cored at $4.5 \mathrm{~km}$ depth in well Radicondoli 29, dumortierite occurs together with andalusite, $\mathrm{Li}$-rich tourmaline, fluorite and fluorapatite. The average composition is $\mathrm{SiO}_{2}:$ 30.9, $\mathrm{Al}_{2} \mathrm{O}_{3}:$ 58.6, FeO: 0.44, $\mathrm{MgO}: 0.47, \mathrm{CaO}: 0.02, \mathrm{~F}: 0.15$. Dumortierite crystallized from supercritical magmatic fluids at $\mathrm{T}=520$ $620^{\circ} \mathrm{C}, \mathrm{P}=100 \pm 30 \mathrm{MPa}$. Synthetic fluid inclusions yielded $\mathrm{T}=510 \pm$ $10^{\circ} \mathrm{C}, \mathrm{P}=42 \pm 3 \mathrm{MPa}$ at $2.9 \mathrm{~km}$ depth in well Venelle 2 . All data suggest present-day $\mathrm{T}=450-550^{\circ} \mathrm{C}, \mathrm{P}=40-80 \mathrm{MPa}$. The supercritical magmatic fluids were hypersaline brines with $\sim 30 \mathrm{wt} \% \mathrm{LiCl}$ and up to $2.4 \mathrm{wt} \% \mathrm{~F}$, extreme contents that can be found only in pegmatites, aplites and leucogranites. Larderello granites derived from partial melting of a lower crust made up of interlayered metasediments and amphibolites. Extensive melting took place in the lower crust during the last $10 \mathrm{Ma}$ owing to extensional tectonics, lithosphere thinning, roll back or break down of the west merging Adria plate and swelling of the asthenosphere below the western side of the Apennines.
\end{abstract}

\section{Dumortierite from sample Rad 29-4548}

Dumortierite, an orthorhombic pseudohexagonal borosilicate, was discovered in well Radicondoli 29 at $4548 \mathrm{~m}$ depth. It is the first report in a geothermal field. Dumortierite is the most abundant B-bearing mineral after tourmaline and occurs frequently together with tourmaline and andalusite in pegmatites, aplites, leucogranites, Al-rich metamorphic and metasomatic rocks and in high temperature hydrothermal systems. The mineral, whose formula is $\mathrm{AlAl}_{6} \mathrm{BSi}_{3} \mathrm{O}_{18}$, shows variable contents of $\mathrm{Fe}, \mathrm{Mg}$, Ti, As, $\mathrm{Sb}, \mathrm{P}, \mathrm{Zn}$. The sample Rad 29-4548 is a porphyritic, hypidiomorphic two-mica monzogranite made up of quartz, orthoclase, oligoclase to andesine plagioclase, biotite, muscovite and cordierite. Quartz crystals, rounded, with embayements, occur as graphic quartz in poikilitic orthoclase. Accessory minerals are tourmaline, dumortierite, fluorite, fluorapatite, zircon and ilmenite. Fluorite occurs as colourless to pale violet blades in cavities and along fractures and cleavages of plagioclase crystals. Dumortierite appears as interstitial prismatic and fibrous

\footnotetext{
* Corresponding author: puxeddu.pisa@gmail.com
} 
crystals, often altered in chlorite and sericite. Pleochroism of prismatic crystals is $\mathrm{X}$ : brown to violet (Fig. 1), Y, Z: pale green, of fibrous crystals: X: greenish blue, Y, Z: pale yellow.

The average composition in wt \% is: $\mathrm{SiO}_{2}: 30.9, \mathrm{Al}_{2} \mathrm{O}_{3}: 58.6, \mathrm{FeO}: 0.44, \mathrm{MgO}: 0.47$, $\mathrm{CaO}: 0.02, \mathrm{~F}: 0.15$. Noteworthy are the complete lack of $\mathrm{TiO}_{2}$ likely due to low content of the host rock $(0.14 \mathrm{wt} \%)$ and the high $\mathrm{F}$ content largely exceeding normal values generally $<0.05$ and rarely in the range $0.05-0.10 \mathrm{wt} \%$.

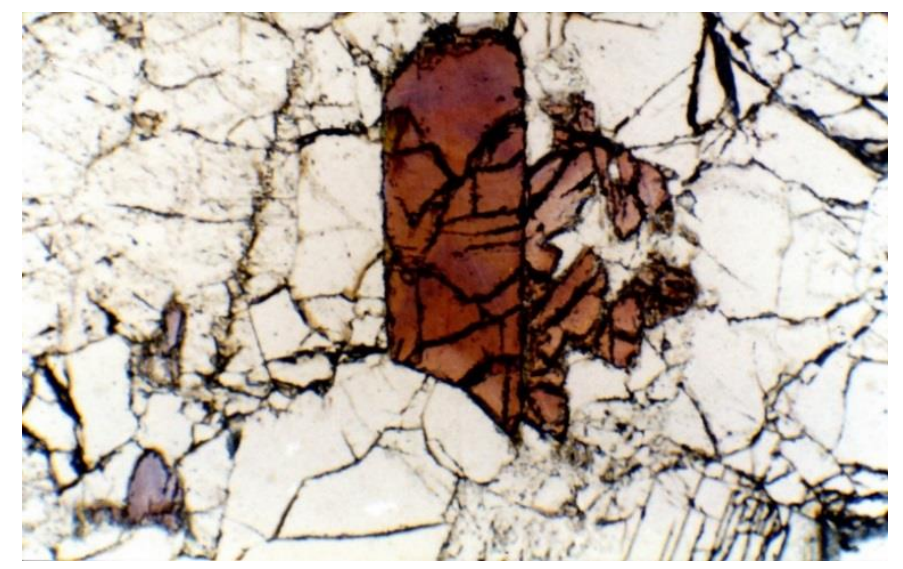

Fig. 1. Photomicrograph: brown prismatic crystal and violet grains of dumortierite. Parallel polars.

\section{Geodynamic and geochronologic framework}

During the collision between Adria and Corsica-Sardinia microplates the eastward roll back of the subduction zone of the west merging Adria plate during the last $10 \mathrm{Ma}$ [1] caused thinning of the Tuscan lithosphere, widespread decompression melting in the mantle and swelling of the asthenosphere below the western side of the Northern Apennines. The underplating of mafic magmas induced partial melting of a lower crust made up of interlayered metasediments and amphibolites giving origin to the peraluminous two-mica granites of the Tuscan Magmatic Province [2]. Several data led researchers to hypothesize the formation of mid-crustal (15-10 km depth) large reservoirs (several hundred $\mathrm{km}^{3}$ ) feeding smaller plutons (tens to hundred $\mathrm{km}^{3}$ ) above 8-6 km depth [2]. New U-Pb zircon data in agreement with ${ }^{40} \mathrm{Ar}^{39} \mathrm{Ar}$ results indicate that Larderello is a multipulse magmatic system embracing five events: 3.8-3.6 Ma; 3.3-3.1 Ma; 2.7-2.5 Ma; 1.9-1.6 Ma and a present-day event [2]. ${ }^{40} \mathrm{Ar}-{ }^{39} \mathrm{Ar}$ ages of $1.23 \pm 0.13 \mathrm{Ma}$ and $1.27 \pm 0.22 \mathrm{Ma}$ were also obtained on muscovites from the monzogranite of Carboli C bis 4200 and the syenogranite of Carboli C bis 4304 respectively [3].

\section{PT conditions of the supercritical magmatic system}

Recently ENEL Green Power public company drilled the well Venelle 2 located in the hottest area of the Larderello geothermal field a few kms from the well San Pompeo 2 characterized by extrapolated well bottom temperatures of $450-460^{\circ} \mathrm{C}$ and suprahydrostatic pressures [4]. From Venelle 2 geochemical, isotope and fluid inclusion data reveal that tourmaline-rich veins and breccias crystallized at $\mathrm{T}=450-550^{\circ} \mathrm{C}, \mathrm{P}=40-80 \mathrm{MPa}$ [2]. The highest homogenization temperatures observed with the method of synthetic fluid inclusions indicate a present-day well bottom $\left(2900 \mathrm{~km}\right.$ depth) temperature of $510 \pm 10^{\circ} \mathrm{C}$ and pressures of $42 \pm 3 \mathrm{MPa}$ [5]. Cogenetic aqueous-carbonic and multiphase hypersaline 
fluid inclusions in San Pompeo 2-2270 sample yielded $\mathrm{T}=495-510^{\circ} \mathrm{C}, \mathrm{P}=70-82 \mathrm{MPa}$ as indicated by the intersection of the isochores [6]. The application of the empirical biotitetourmaline geothermometer [7] on 27 pair of the two minerals from the well bottom sample SanPompeo 2-2962 yielded 21 temperature values in the range $540-585^{\circ} \mathrm{C}, 4$ values in the range $518-540^{\circ} \mathrm{C}$ and two values of $618^{\circ} \mathrm{C}$ and $622^{\circ} \mathrm{C}$ (unpublished data [4]). The last values are consistent with the nearby occurrence of corundum and xenoblastic sanidine generated by the muscovite breakdown that took place at $\mathrm{T}=610-620^{\circ} \mathrm{C}$ and $\mathrm{P}=1 \mathrm{~kb}(100$ $\mathrm{MPa}$ ) [8]. All data collected in well San Pompeo 2 suggest that tourmaline and associated dumortierite in $\operatorname{Rad} 29-4548$ were deposited during a previous thermal event $(\sim 1.3-1.2 \mathrm{Ma}$ in Carboli $\mathrm{C}$ bis?) at PT conditions estimated to be $400-600^{\circ} \mathrm{C}, 0.75-1 \mathrm{~kb}(75-100 \mathrm{MPa})$ [4] or $425-650^{\circ} \mathrm{C}, 100-130 \mathrm{MPa}$ [9], $100-120^{\circ} \mathrm{C}, 60-70 \mathrm{MPa}$ higher than the present-day supercritical PT conditions ascertained through the method of synthetic fluid inclusions.

\section{Evolution of the supercritical magmatic system}

The Larderello granites crossed by several deep drillings (Radicondoli and Carboli $\mathrm{C}$ bis) are syenogramites to monzogranites with73.8 to $78.7 \mathrm{wt} \% \mathrm{SiO}_{2}, 11.9$ to 13.9 wt $\% \mathrm{Al}_{2} \mathrm{O}_{3}$, 4.65 to 5.38 wt $\% \mathrm{~K}_{2} \mathrm{O}, 2.50$ to 3.65 wt $\% \mathrm{Na}_{2} \mathrm{O}$ [3]. These granitic melts, originally strongly enriched in $\mathrm{B}, \mathrm{Li}, \mathrm{F}$, at the end of crystallization produced magmatic supercritical fluids with temperatures slightly lower than granite solidus in hydrothermal environment characterized by lithostatic pressures and separated from the shallower meteoric system by an impermeable barrier [4]. $\mathrm{Li}$ in supercritical fluids is revealed by extremely low eutectic temperatures ranging from -78 to $-65^{\circ} \mathrm{C}$ typical of the $\mathrm{LiCl} \cdot 5 \mathrm{H}_{2} \mathrm{O}$ system, while ice melting temperature of $-25^{\circ} \mathrm{C}$ indicates a mean salinity of $\sim 30 \mathrm{wt} \% \mathrm{LiCl}$ equivalent [9]. High Li contents are also revealed by tourmaline crystal cores in the leucogranitic centimetre-thick dyke of sample VC 11-2946 whose compositions show a trend towards tourmalines from Li-rich granitoid pegmatites and aplites [4]. A confirmation of the high $\mathrm{F}$ contents of the Larderello granites is given by the occurrence of abundant grains of fluorite and fluorapatite and by the unusual very high average F content of dumortierite $(0.15 \mathrm{wt} \%)$ generally lower than $0.05 \mathrm{wt} \%$. Extremely high $\mathrm{F}$ contents were found in muscovites from the Larderello granites particularly in the last silicic differentiates, such as syenogranite Carboli $\mathrm{C}$ bis 4304 in which several muscovites exceed the world record of $2.13 \mathrm{wt} \% \mathrm{~F}$ found in a muscovite from the Macusani ignimbrite [10], attaining a maximum value of 2.93 wt \% [3]. B does not show high content in the Larderello granites probably because its concentration, with progressing crystallization, was generally enriched only in the last residual fluids that gave origin to dumortierite along grain boundaries and tourmaline in breccias and miarolitic cavities. The abundance of boron in the Larderello granites and in the whole Tuscan Magmatic Province is explained by the metasedimentary nature of the source rocks located in the fertile lower crust. Moreover, the Larderello granites are also remarkably enriched in Li and F. In these cases (see Fig.2) the granite solidus [3] is more and more leftwards shifted even for some hundreds $\mathrm{T}^{\circ} \mathrm{C}$ as testified by the experimental granite solidus for Macusani glass (MAC), Harding pegmatite (HAR), Beauvoir granite (BV) and for synthetic granitic melts with 1 wt $\% \mathrm{~B}_{2} \mathrm{O}_{3}, 2$ wt $\% \mathrm{~F}$ [10], lowering the crystallization for muscovite-bearing granites to the temperature range $\sim 550-630^{\circ} \mathrm{C}$ at pressures just slightly above and below $100 \mathrm{MPa}$ (elliptical field). The contemporaneous rightwards shifting of the pure muscovite-out reaction (Ms Ab- As Kfs vapor solid line) towards that of two Macusani ignimbrites with 0.68 and $2.13 \mathrm{wt} \% \mathrm{~F}$ lowers the intersection with the solidus of B-, F-, Li-rich granites towards lower and lower pressure values comparable with those of the present-day supercritical magmatic fluids with only a concomitant slight temperature increase. All the currently available data from geochemistry 
and petrology, included the most recent ones, confirm the hypothetical position of the LAR granite solidus in the PT range depicted with the shaded area between the dashed lines of Fig. 2.

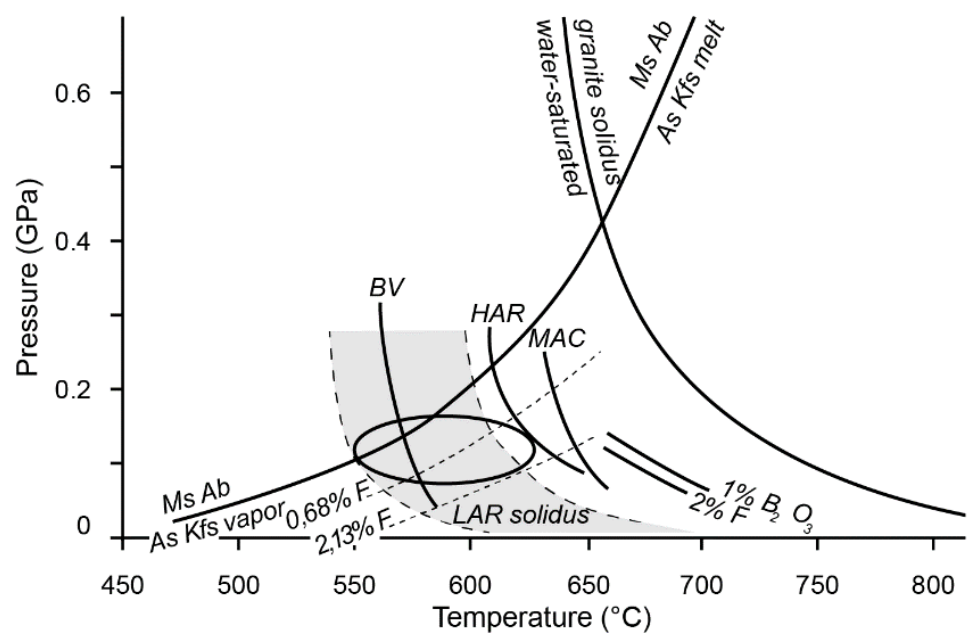

Fig. 2. Evolution of the Larderello granitic melts from the water saturated granite solidus towards the solidus of melts more and more enriched in $\mathrm{B}, \mathrm{Li}, \mathrm{F}$. Muscovite-out reaction (Ms Ab vs As Kfs vapor) for pure end member (solid line) and with 0.68 and $2.13 \mathrm{wt} \% \mathrm{~F}$ (dotted lines); experimental granite solidus (thick lines) for Macusani glass (MAC), Harding pegmatite (HAR), Beauvoir granite (BV) and for synthetic granites with addition of $1 \mathrm{wt} \% \mathrm{~B}$ and $2 \mathrm{wt} \% \mathrm{~F}$ [10]; crystallization field of muscovite granite (open elliptical field), hypothetical position of the LAR granite solidus (grey field bounded by dashed lines).

\section{References}

1. F. Mongelli, F. Palumbo, M. Puxeddu, I.M. Villa, G. Zito, Mem. Soc. Geol. It., 52, 305-318 (1998)

2. A. Dini, C. Boschi, F. Farina, M. Laurenzi, L. Peruzzo, G. Ruggieri, U. Schaltegger, Proc. DESCRAMBLE Final Conf., Pisa, Italy, 10-11 (2018)

3. A. Dini, G. Gianelli, M. Puxeddu, G. Ruggieri, Lithos 81, 1-31 (2005)

4. G. Cavarretta, M. Puxeddu, Econ. Geol., 85, 1236-1251 (1990)

5. G. Ruggieri, A. Dini, A. Orlando, L. Peruzzo, Proc. DESCRAMBLE Final Conf., Pisa, Italy, 29-30 (2018)

6. G. Ruggieri, Proc. DESCRAMBLE Final Conf., Pisa, Italy, 70-71 (2018)

7. M. R. Colopietro, L. M. Friberg, Black Hills, South Dakota, Geol. Soc. Am. Abstr.Progr. 19, 624 (1987)

8. A. Del Moro, M. Puxeddu, F. Radicati di Brozolo, I. M. Villa, Contrib. Mineral. Petrol., 81, 340-349 (1982)

9. M. Cathelineau, C. Marignac, M. C. Boiron, G. Gianelli, M. Puxeddu, Geochim. Cosmochim. Acta, 58, 1083-1099 (1994)

10. M. Pichavant, D. J. Kontakt, L. Briqueu, J. Valencia Herrera, A. H. Clark, Contrib. Mineral. Petrol.,100, 325-338 (1988) 